\title{
Immediate impact of percutaneous transvenous mitral commissurotomy on right ventricular function
}

\author{
Bishal KC, ${ }_{1}^{1}$ Rabi Malla, ${ }^{2}$ Ram Kishore Shah, ${ }^{1}$ Anish Hirachan, ${ }^{1}$ Binay Kumar Rauniyar, ${ }^{2}$ Deepak Limbu, ${ }^{2}$ \\ Milan Gautam, ${ }^{2}$ Amit Kumar Agrawal, ${ }^{1}$ Miqdaadh Shareef, ${ }^{1}$ Arun Maskey, ${ }^{2}$ Man Bahadur KC, ${ }^{2}$ \\ Chandra Mani Adhikari, ${ }^{2}$ Rajib Rajbhandari, ${ }^{2}$ Deewaker Sharma ${ }^{2}$
}

\author{
1 Department of Cardiology, National Academy of Medical Sciences, Bir Hospital, Kathmandu \\ 2 Department of Cardiology, Shahid Gangalal National Heart Center, Kathmandu, Nepal
}

Corresponding author: Bishal KC,

Department of Cardiology,

National Academy of Medical Sciences, Bir Hospital, Kathmandu Nepal,

Email address: bishalk@gmail.com

\section{Abstract}

\begin{abstract}
Background and Aims: Abnormal Right Ventricular (RV) function affects the long term outcome and clinical symptoms in patients with mitral stenosis (MS). This study evaluates the immediate effect of Percutaneous Transmitral Commisurotomy (PTMC) on RV function.

Methods: An observational, cross sectional study was done on 50 patients with rheumatic MS who underwent PTMC at Shahid Gangalal National Heart Center from Dec 2015 -Dec 2016. All underwent clinical evaluation and echocardiogram before and immediately after PTMC.

Results: There was female preponderance with $66 \%$ being female. The mean age was $37.26 \pm 10.63$ years. There was immediate increase in the mitral valve area (MVA) from $0.87 \pm 0.12 \mathrm{~cm} 2$ to $1.54 \pm 0.27 \mathrm{~cm} 2(\mathrm{p}<0.001)$. There was significant decrease in mean mitral diastolic gradient from $16.4 \pm 8.8 \mathrm{mmHg}$ to $5 \pm 1.5 \mathrm{mmHg}(\mathrm{p}<0.001)$, in the pulmonary artery systolic pressure $53.6 \pm 21.83 \mathrm{mmHg}$ to $39.5 \pm 14.67 \mathrm{mmHg}(\mathrm{p}<0.001)$, in the RV Tei index from 0.56 \pm 0.08 to $0.40 \pm 0.08(\mathrm{p}<0.001)$. There was significant increase in TAPSE from $16.0 \pm 1.50$ to $18.6 \pm 1.70 \mathrm{~mm},(\mathrm{p}<0.001)$ and the longitudinal velocity of excursion of the RV at the tricuspid annulus (RV S') from $13.69 \pm 3.33 \mathrm{~cm} / \mathrm{sec}$ to 15.31 $\pm 3.07 \mathrm{~cm} / \mathrm{sec}(\mathrm{p}<0.001)$

Conclusions: Successful PTMC can improve RV function as shown by the improvement in PASP, RV Tei index, TAPSE and RV S'. Further larger population studies are required to confirm the findings. Long term studies are important to determine the prognostic significance of improvement in RV function.
\end{abstract}

Key words: Mitral stenosis; Percutaneous Transmitral Commisurotomy; Right Ventricular function.

DOI: http://dx.doi.org/10.3126/njh.v14i2.18498

\section{Introduction}

Mitral Stenosis (MS) is the commonest of all rheumatic heart disease. ${ }^{1}$ It is a mechanical disorder and natural history is significantly altered with an improvement in mortality by intervention with Percutaneous Transmitral Commisurotomy (PTMC) or surgery. 2,3,4

The RV function is an important determinant of clinical symptoms, exercise capacity, pre-operative survival and postoperative outcome in these patients. ${ }^{5} \mathrm{MS}$ leads to increase in left atrial pressure due to the back pressure, results in passive rise in pulmonary venous and arterial pressures and causes RV dysfunction. ${ }^{6} \mathrm{RV}$ dysfunction is also due to rheumatic process when it involves the myocardium, thus directly impairs RV function.?

The Echocardiographic parameters of RV function are RV ejection fraction, RV fractional area change, RV total ejection isovolume index (Tei index) and tricuspid annular plane systolic excursion. ${ }^{8}$ RVTei index may be more effective for analysis of global cardiac dysfunction than systolic and diastolic measure alone. ${ }^{9}$

Since its introduction in 1984 by Inoue et al. ${ }^{10}$ PTMC is a safe and effective treatment for rheumatic MS and is treatment of choice in patients with a favorable anatomy. ${ }^{11,12,13}$ PTMC has been performed regularly in Shahid Gangalal National Heart Centre for the last 17 years. ${ }^{14,15,16}$ Till now there is no data regarding the impact of PTMC on the RV function in our population. Thus we aim to study the impact of PTMC on RV function.

This was a cross sectional single center hospital based study. The study population included 50 consecutive patients admitted in Shahid Gangalal National Heart Center with the diagnosis of Mitral Stenosis for PTMC. Ethical approval was taken prior to the conduct of the study and informed consent was taken. The study period was from December 2015 to June 2016. The sample size

@Nepalese Heart Journal. Nepalese Heart Journal retains copyright and work is simultaneously licensed under Creative Commons Attribution License CC - BY 4.0 that allows others to share the work with an acknowledgement of the work's authorship and initial publication in this journal. 
was calculated using the proportional formula.

The following were the inclusion and exclusion criteria

\section{Inclusion Criteria:}

Patients admitted in SGNHC, irrespective of age \& sex with the diagnosis of symptomatic mitral stenosis that subsequently undergone PTMC (fulfilling criteria of indications).

\section{Exclusion criteria:}

- Patients with contraindication for PTMC

- Systemic hypertension

- Diabetes Mellitus

- Patients with documented coronary artery disease requiring surgical revascularization

- Chronic lung disease

- New York Heart Association functional class IV.

\section{Study Protocol:}

The ethical clearance was taken prior to conduct the study from the ethical committee. Informed consent was taken from all the patients before the procedure. Detail clinical evaluation and echocardiogram was done. All patients underwent following examination:

1. History, physical examination and cardiovascular examination

2. Electrocardiogram (ECG)

3. Chest roentgenogram

4. Baseline blood investigation

5. Echocardiogram

\section{Echocardiographic measurements}

Two-dimensional (2D) echocardiography and Doppler studies were performed before and immediately after PTMC within 24 hour. The same echocardiographer performed all measurements using the recommendations of the American Society of Echocardiography. ${ }^{17}$ Mitral valve area (MVA) was determined by planimetry in every patient. The peak and mean mitral valve transannular pressure gradients and late filling velocities were measured using the Bernoulli principle from continuous wave Doppler recordings through the centre of mitral inflow. Systolic pulmonary artery pressure was derived from the tricuspid regurgitant jet peak velocity using the modified Bernoulli equation (peak gradient $4 \mathrm{~V}^{2}$, where $\mathrm{V}$ is the maximal velocity of the tricuspid regurgitant jet).

Tricuspid Annular Plane Systolic Excursion (TAPSE): It was determined by the difference in the displacement of the RV base during systole and diastole. TAPSE was acquired by placing an M-mode cursor through the tricuspid annulus and measuring the amount of longitudinal motion of the annulus at peak systole. ${ }^{18}$
RV Tei Index: In apical 4 chamber view a sample volume (Pulsed wave Doppler) placed at the tricuspid valve. RVTei Index calculated as the sum of isovolumic contraction time (IVCT) and isovolumic relaxation time (IVRT) divided by ejection time (ET). ${ }^{19}$

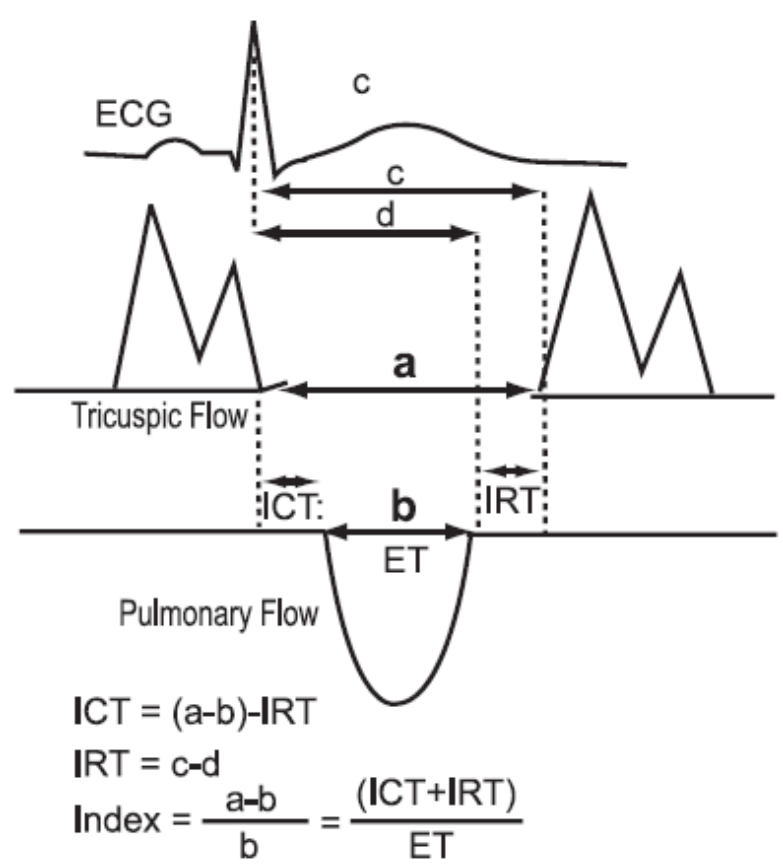

Fig: Measurement of RVTei index.

Percutaneous transveneous mitral commissurotomy

All patients underwent PTMC by the technique described by inoue et al by the antegradetranseptal approach. ${ }^{20}$ The nominal diameter was decided according to the height of the patient [i.e height $(\mathrm{cm}) / 10+10=$ balloon diameter.$^{21}$

\section{Statistical analysis}

The calculations were done by Microsoft Excel 2007 and Statistical Package for Social Sciences, SPSS version 20; and the data were presented in the form of tables and diagrams. Categorical value was expressed as percentage. Continuous variable expressed as measured as mean +/- SD. Normal distribution of our population was checked by Shapiro-Wilk test and was found to be normally distributed. Significance of the results pre and post PTMC was analyzed employing student's paired t-test. A P-value $<0.05$ was considered statistically significant.

\section{RESULT}

The mean age was $37.26 \pm 10.63$ years. Table 1 shows the baseline characteristics of the patients who underwent PTMC. Sixty six percent of the total was female and $34 \%$ were male. There was no significant difference with respect to height, weight, BMI and BSA among both sexes. The history of rheumatic fever prophylaxis was present in $39 \%$ of the total patients. Past history of surgery was present in $6 \%$ of the patients. Fourteen percent of them had previous PTMC. Atrial fibrillation was present in the presenting ECG in $46 \%$ of the patients. 
Table 1:- Baseline characteristics of the patients with Mitral Stenosis undergoing PTMC

\begin{tabular}{|c|c|c|c|c|}
\hline Characteristic & $\begin{array}{l}\text { Male } \\
(\mathrm{n}=17)\end{array}$ & $\begin{array}{l}\text { Female } \\
(\mathrm{n}=33)\end{array}$ & $\begin{array}{l}\text { Overall } \\
(\mathrm{n}=50)\end{array}$ & $\mathrm{p}$ Value \\
\hline Age (Years) & $38.18 \pm 11.22$ & $36.79 \pm 10.46$ & $37.26 \pm 10.63$ & 0.66 \\
\hline Height (Cm) & $156.35 \pm 8.47$ & $153.57 \pm 5.44$ & $154.52 \pm 6.67$ & 0.166 \\
\hline Weight $(\mathrm{Kg})$ & $49.05 \pm 9.91$ & $48.12 \pm 7.32$ & $48.44 \pm 8.20$ & 0.706 \\
\hline $\begin{array}{l}\text { Body Mass Index (Kg/ } \\
\text { m2) }\end{array}$ & $19.78 \pm 4.24$ & $20.12 \pm 2.62$ & $20.00 \pm 3.22$ & 0.733 \\
\hline Body Surface Area (BSA) & $1.46 \pm 0.15$ & $1.42 \pm 0.12$ & $1.48 \pm 0.13$ & 0.359 \\
\hline RF Prophylaxis & $14(82.4 \%)$ & $25(75.8 \%)$ & $39(78 \%)$ & 0.44 \\
\hline History of Past Surgery & $1(5.9 \%)$ & $2(6.1 \%)$ & $3(6 \%)$ & 0.736 \\
\hline Previous PTMC & $3(17.6 \%)$ & $4(12.1 \%)$ & $7(14 \%)$ & 0.446 \\
\hline ECG with AF & $10(58.8 \%)$ & $13(39.40 \%)$ & $23(46 \%)$ & 0.157 \\
\hline
\end{tabular}

Table 2: Presenting complaints of the patients

\begin{tabular}{lll} 
Presenting complains & Number (\%) & P value \\
\hline Palpitation & $34(68 \%)$ & 0.09 \\
\hline Fatigue & $30(60 \%)$ & 0.151 \\
\hline Chest pain & $9(18 \%)$ & 0.341 \\
\hline Ankle edema & $8(16 \%)$ & 0.44 \\
\hline Hemoptysis & $5(10 \%)$ & 0.44 \\
\hline Dizziness & $1(2 \%)$ & 0.34 \\
\hline Shortness of breath & $40(80 \%)$ & 0.03
\end{tabular}

Table 2 demonstrates the mode of clinical presentation. Majority $(80 \%)$ of the patients complained shortness of breath, followed by $68 \%$ palpitation, $30 \%$ fatigue, $18 \%$ chest pain and $10 \%$ Hemoptysis and $1 \%$ dizziness.

Table 3: NYHA functional class pre and post PTMC

\begin{tabular}{|lllll} 
NYHA functional class & Pre PTMC & \multicolumn{3}{c}{ Post PTMC } \\
\hline & Number & \% & Number & $\%$ \\
\hline I & 0 & 0 & 14 & 28 \\
II & 22 & 44 & 20 & 40 \\
\hline III & 28 & 56 & 16 & 32
\end{tabular}

Table 3 shows more than half of the patients were in NYHA functional Class III 26 (56.0\%) followed by class II 22 (44.0\%). After procedure, 14 (28.0\%) of the show symptoms of class I, 20 (40.0\%) in class II and 16 (32.0\%) in class III.

\begin{tabular}{|c|c|c|c|c|}
\hline Variables & $\begin{array}{l}\text { Pre PTMC } \\
(\mathrm{n}=50)\end{array}$ & $\begin{array}{l}\text { Post PTMC } \\
(n=50)\end{array}$ & $\begin{array}{l}\text { Mean Change (95\% Confidence } \\
\text { Interval) } \\
(\mathrm{n}=50)\end{array}$ & $\mathrm{p}$ Value \\
\hline MVA (cm2) & $0.87 \pm 0.12$ & $1.54 \pm 0.27$ & $0.66 \pm 0.29(0.58-0.74)$ & $<0.001$ \\
\hline Mean gradient & $16.4 \pm 8.8$ & $5 \pm 1.5$ & $-11.4 \pm 4.6(-2.33--20.46)$ & 0.013 \\
\hline LVESd $(\mathrm{Cm})$ & $3.03 \pm 0.41$ & $3.09 \pm 0.42$ & $0.05 \pm 0.24(0.01-0.12)$ & 0.131 \\
\hline LVEDd (Cm) & $4.41 \pm 0.56$ & $4.56 \pm 0.44$ & $0.14 \pm 0.36(0.04-0.24)$ & 0.073 \\
\hline LVEF (\%) & $62.3 \pm 5.23$ & $62.42 \pm 4.20$ & $0.12 \pm 4.4(-1.39-1.15)$ & 0.851 \\
\hline IVS (Cm) & $0.74 \pm 0.11$ & $0.76 \pm 0.11$ & $0.015 \pm 0.07(0.005-0.03)$ & 0.144 \\
\hline
\end{tabular}




\begin{tabular}{llllll}
\hline Table 5:-Echocardiographic data of right heart dimension of Pre and post PTMC & & $\begin{array}{l}\text { Post PTMC } \\
\text { Variables }\end{array}$ & $\begin{array}{l}\text { Pre PTMC } \\
(\mathrm{n}=50)\end{array}$ & $\begin{array}{l}\text { Mean Change (95\% } \\
\text { Confidence Interval) } \\
(\mathrm{n}=50)\end{array}$ & P value \\
\hline RA dimension $\left(\mathrm{cm}^{2}\right)$ & $14.02 \pm 4.71$ & $13.79 \pm 4.93$ & $-0.22 \pm 2.11(-0.37-0.82)$ & 0.458 \\
\hline RVOT Dimension $(\mathrm{mm})$ & $2.47 \pm 0.34$ & $2.27 \pm 0.29$ & $-0.20 \pm 0.38(-0.09--0.31)$ & 0.001 \\
RV wall thickness $(\mathrm{mm})$ & $6.16 \pm 0.91$ & $6.02 \pm 0.79$ & $-0.14 \pm 0.57(-0.3-0.02)$ & 0.05
\end{tabular}

$R A$ - right atrium, $R V O T$ - right ventricular outflow tract, $R V$ - right ventricle

\begin{tabular}{llll}
$\begin{array}{l}\text { Table 6: Hemodynamic function and RV parameters between pre and post PTMC } \\
\text { Characteristic }\end{array}$ & Pre PTMC & Post PTMC & $\begin{array}{l}\text { Mean Change (95\% Confidence } \\
\text { Interval) }\end{array}$ \\
& $(\mathrm{n}=50)$ & $(\mathrm{n}=50)$ & $(\mathrm{n}=50)$ \\
& $10.04 \pm 0.83$ & $10.1 \pm 0.70$ & $0.06 \pm 0.42(-0.06-0.18)$ \\
\hline RA Pressure $(\mathrm{mm} \mathrm{Hg})$ & $53.6 \pm 21.83$ & $39.5 \pm 14.67$ & $-14.1 \pm 10.61(-11.08--17.11)$ \\
\hline PASP $(\mathrm{mm}$ of Hg) & $16.0 \pm 1.50$ & $18.6 \pm 1.70$ & $0.12 \pm 3.4(-0.85-1.09)$ \\
\hline TAPSE $(\mathrm{cm})$ & $0.56 \pm 0.08$ & $0.40 \pm 0.08$ & $-0.15 \pm 0.12(-0.12--0.19)$ \\
\hline TEI Index & $13.69 \pm 3.33$ & $15.31 \pm 3.07$ & $1.62 \pm 2.06(1.03-2.20)$
\end{tabular}

RA- right atrium, PASP-pulmonary artery systolic pressure, TAPSE- tricuspid annular plane systolic excursion

Left heart parameters among the patient who underwent PTMC was shown in table 4 . There was significant change in mean mitral valve area $(0.87 \pm 0.12$ to $1.54 \pm 0.27) \mathrm{cm} 2(\mathrm{p}<0.001)$ which turns out to be approximately $66 \%$ increase in the MVA. The mean transmitral gradient was decreased by $69 \%(16.4+8.8$ to $5+1.5)$ mmHg. The LVESd, LVEDd, LVEF, IVS remained stable which were statistically not significant.

Table 5 shows the changes in the right heart dimension after PTMC. The decrease in RA area was not statistically significant. The decrease in RVOT and RV dimension was significant.

Hemodynamic changes and the changes in the RV parameters after PTMC was shown in Table 6. There was no any significant change in the right atrial pressure. There was significant reduction of the pulmonary artery systolic pressure $(53.6 \pm 21.83$ to $39.5 \pm 14.67) \mathrm{mmHg}(\mathrm{p}<0.001)$ approximately by $26 \%$. There was significant slight increase TAPSE from 16.0 $\pm 1.50 \mathrm{~mm}$ to $18.6 \pm 1.70(\mathrm{p}<0.001)$. Doppler index for global right ventricular function immediately after PTMC showed significant reduction of the index $(0.56 \pm 0.08$ to $0.40 \pm 0.08)$ $(\mathrm{p}<0.001)$. The longitudinal velocity of excursion of the right ventricle at the tricuspid annulus termed RV S' also showed significant improvement $(13.69 \pm 3.33$ to $15.31 \pm 3.07) \mathrm{cm} / \mathrm{sec}(\mathrm{p}<$ $0.001)$.

\section{Discussion}

Right ventricular function impairment in mitral stenosis occurs both due to the myocardial disease process and increase in RV afterload. Abnormalities of the RV function play a significant role in the development of the overall symptoms and prognosis of mitral stenosis. Assessment of $\mathrm{RV}$ function is therefore an important in evaluation of mitral stenosis particularly after a procedure. Because of its trapezoid anatomy this assessment is particularly difficult. There are different techniques put forwarded for assessment however none of them is the gold standard. In practice most relies on the two modalities: two-dimensional echocardiography and DTI echocardiography. TAPSE is considered to reflect the global systolic function. ${ }^{18,22,23}$ The tei index reflects both systolic and diastolic function. ${ }^{23}$

The findings in our study show that patients with MS have depressed global and regional RV function as shown in table 4. These findings are in accordance with previous radionuclide and haemodynamic studies. ${ }^{5}$ There are no any conclusive explanation of such dysfunction and is controversial. ${ }^{24}$ Some studies conducted earlier and paper published suggests that the rheumatic pathologic process may directly affect the myocardium to cause dysfunction. ${ }^{25,26}$ There has been histomorphological studies of rheumatic heart disease which showed that intramyocardial branches of coronary vessels were involved in a form of active rheumatic vasculitis or inactive lesions characterized by medial hypertrophy and replacement fibrosis. They believe this might contribute to the dysfunction seen. ${ }^{26}$ The other factor that might cause RV functional impairment is the increase in LA pressure that acts passively to increase pulmonary artery pressure and reactive changes in pulmonary arteriolar resistance may lead to increased RV afterload and RV failure. ${ }^{27}$

Our study showed significant increase in TAPSE from $16.0 \pm 1.50$ to $18.6 \pm 1.70 \mathrm{~mm}, \mathrm{p}<0.001$. This result is comparable to the study done by Ragab et al. ${ }^{28}$ in which they found the TAPSE increased significantly after PTMC from $17.1 \pm 2.1$ to $19.1 \pm 2.5, \mathrm{p}<0.05$. There has been mixed findings in other studies. The study done by Bensaid et al. ${ }^{29}$ and Drighil et al. ${ }^{8}$ noticed a non significant change in TAPSE after PTMC.

Our study shows there is significant decrease in RV Tei index (table 6) which shows improvement in both systolic as well as diastolic RV function post PTMC. We observed that the RV Tei index decreased after PTMC from $0.56 \pm 0.08$ to $0.40 \pm 0.08, \mathrm{p}<0.001$. This findings was comparable to the study done by Drighil et al ${ }^{8}$ where they found RV Tei index decreased from $0.44 \pm 0.25$ to $0.29 \pm 0.17(\mathrm{p}<0.001)$ and Kundu et al. ${ }^{30}$ found the decrease in RV Tei was from $0.50 \pm 0.10$ to $0.30 \pm 0.10$ 
$(\mathrm{p}<0.001)$.In one of the study conducted by Borges et al. ${ }^{31}$ who demonstrated an improvement in Tei index after vasodilatator therapy in patients with chronic pulmonary hypertension.

\section{PASP:}

Our study showed significant decrease in the PASP from $53.6 \pm$ 21.83 to $39.5 \pm 14.67(\mathrm{p}<0.001)$. the study conducted by Drighil et $\mathrm{al}^{8}$ showed reduction of PASP from $46.4 \pm 32.1 \mathrm{mmHg}$ to 29.1 $\pm 13.4 \mathrm{mmHg}(\mathrm{P}=0.02)$. Kundu ${ }^{30}$ et al showed reduction from $47.7 \pm 7.9$ to $28.2 \pm 5.9(\mathrm{p}<0.001)$. Similar results were also seen in other studies conducted by Mohan JC et.al.

\section{Systolic excursion velocity (RV S')}

In our study the there was significant improvement in the systolic excursion velocity from $13.69 \pm 3.33$ to $15.31 \pm 3.07(\mathrm{p}<0.001)$. Bensaidet al. ${ }^{29}$ observed a non-significant increase in tricuspid annular systolic myocardial velocity. Drighilet al. ${ }^{8}$ found that systolic myocardial velocity did not change immediately after PTMC.

Small sample size and no long term follow up are the main limitation of this study.

\section{Conclusion}

The study shows that there is improvement in RV functions after the after load reducing procedure such as PTMC. Further studies with large population needs to be done to confirm the results of this study and also to assess its utility in follow up, prognosis and long term benefit.

\section{References:}

1. Okubo S, Nagata S, Masuda Y, Kawazoe K, Atobe M, Manbe, H. Clinical feature of rheumatic fever in Bangladesh. Japanese Circulation Journal 1984;48:1345 - 49.https://doi. org/10.1253/jcj. 48.1345

2. Ellis LB, Singh JB, Morales DD, Harken DE. Fifteen-to twenty-year study of one thousand patients undergoing closed mitral valvuloplasty. Circulation 1973; 48:357.https:// doi.org/10.1161/01.CIR.48.2.357

3. OrrangeSE, Kawanishi DT, Lopez BM, Curry SM, Rahimtoola SH. Actuarial outcome after catheter balloon commissurotomy in patients with mitral stenosis. Circulation. 1997 Jan 21;95(2):382-9.https://doi.org/10.1161/01. CIR.95.2.382

4. Bonow RO, Carabello BA, Chatterjee K, de Leon AC, Faxon DP, Freed MD, Gaasch WH, Lytle BW, Nishimura RA, O'Gara PT, O'Rourke RA. 2008 focused update incorporated into the ACC/AHA 2006 guidelines for the management of patients with valvular heart disease: a report of the American College of Cardiology/American Heart Association Task Force on Practice Guidelines (Writing Committee to revise the 1998 guidelines for the management of patients with valvular heart disease) Endorsed by the Society of Cardiovascular Anesthesiologists, Society for Cardiovascular Angiography and Interventions, and Society of Thoracic Surgeons. Journal of the American College of Cardiology. 2008 Sep 23;52(13):e1-42.https://doi.org/10.1016/j. jacc.2008.05.007

5. Mohan JC, Sengupta PP, Arora R. Immediate and delayed effects of successful percutaneous transvenous mitral commissurotomy on global right ventricular function in patients with isolated mitral stenosis. International journal of cardiology. 1999 Feb 28;68(2):217-23.https://doi. org/10.1016/S0167-5273(98)00358-1
6. Dalen J, Fenster P. Mitral stenosis. In: Alpert JS, Dalen JE, Rahimtoola SH, editors. Valvular heart disease. Philadelphia: Lippincott Williams \& Wilkins; 2000. p. 347-66, 3:(22).

7. BurgerW,Kneissl GD, Kober G, Schräder R. Effect of balloon valvuloplasty for mitral stenosis on right ventricular function. The American journal of cardiology. 1993 Apr 15;71(11):9946.https://doi.org/10.1016/0002-9149(93)90921-X

8. Drighil A, Bennis A, Mathewson JW, Lancelotti P, Rocha P. Immediate impact of successful percutaneous mitral valve commissurotomy on right ventricular function. European Journal of Echocardiography 2008; 9:536-541.https://doi. org/10.1093/ejechocard/jen126

9. Bruch C, Schmermund A, Marin D, Katz M, Bartel T, Schaar $\mathrm{J}$, Erbel R. Tei-index in patients with mild-to-moderate congestive heart failure. European heart journal. $2000 \mathrm{Nov}$ 1;21(22):1888-95.https://doi.org/10.1053/euhj.2000.2246

10. Inoue K, Owaki T, Nakamura T, Kitamura F, Miyamoto N. Clinical application of transvenous mitral commissurotomy by a new balloon catheter. The Journal of thoracic and cardiovascular surgery. 1984 Mar;87(3):394-402.

11. Iung B, Garbarz E, Michaud P, Helou S, Farah B, Berdah P, Michel PL, Cormier B, Vahanian A. Late results of percutaneous mitral commissurotomy in a series of 1024 patients. Circulation. 1999 Jun 29;99(25):3272-8.https://doi. org/10.1161/01.CIR.99.25.3272

12. Vahanian A, Baumgartner H, Bax J, Butchart E, Dion R, Filippatos G, Flachskampf F, Hall R, Iung B, Kasprzak J, Nataf P. Task Force on the management of valvular heart disease of the European Society of Cardiology; ESC Committee for Practice Guidelines. Guidelines on the management of valvular heart disease: the task force on the management of valvular heart disease of the European Society of Cardiology. Eur Heart J. 2007;28(2):230-68.

13. Nishimura RA, Carabello BA, Faxon DP, Freed MD, Lytle BW, O'Gara PT, O'Rourke RA, Shah PM. ACC/AHA 2008 Guideline update on valvular heart disease: focused update on infective endocarditis: a report of the American College of Cardiology/American Heart Association Task Force on Practice Guidelines endorsed by the Society of Cardiovascular Anesthesiologists, Society for Cardiovascular Angiography and Interventions, and Society of Thoracic Surgeons. Journal of the American College of Cardiology. 2008 Aug 19;52(8):676-85.https://doi.org/10.1016/j. jacc.2008.05.008

14. Adhikari CM. Percutaneous Transluminal Mitral Commisuriotomy for Mitral Stenosis in ShahidGangalal National Heart Centre, Kathmandu, Nepal. Nepalese Heart Journal. 2016;13(2):15-7.https://doi.org/10.3126/njh. v13i2.15557

15. Shrestha M, Adhikari CM, Shakya U, Khanal A, Shrestha S, Rajbhandari R. Percutaneous Transluminal Mitral Commissurotomy in Nepalese children with Rheumatic Mitral Stenosis. Nepalese Heart Journal. 2014 Feb 1;10(1):23-6.https://doi.org/10.3126/njh.v10i1.9743

16. KC MB. Rheumatic Heart Disease in Nepal: Current Scenario. Nepalese Heart Journal. 2016;13(2):1-2.https:// doi.org/10.3126/njh.v13i2.15554

17. Schiller NB, Shah PM, Crawford M, DeMaria A, Devereux R, Feigenbaum H, Gutgesell H, Reichek N, Sahn D, Schnittger I, Silverman NH. Recommendations for quantitation of the left ventricle by two-dimensional echocardiography. Journal of the American Society of Echocardiography. 1989 Sep 1;2(5):358-67.https://doi.org/10.1016/S08947317(89)80014-8

18. Ghio S, Recusani F, Klersy C, Sebastiani R, Laudisa ML, 
Campana C, Gavazzi A, Tavazzi L. Prognostic usefulness of the tricuspid annular plane systolic excursion in patients with congestive heart failure secondary to idiopathic or ischemic dilated cardiomyopathy. The American journal of cardiology. 2000 Apr 1;85(7):837-42.https://doi.org/10.1016/S00029149(99)00877-2

19. Tayyareci Y, Nisanci Y, Umman B, Oncul A, Yurdakul S, Altun I, Umman S, Bugra Z. Early detection of right ventricular systolic dysfunction by using myocardial acceleration during isovolumic contraction in patients with mitral stenosis. European Heart Journal-Cardiovascular Imaging. 2008 Jan 1.

20. Inoue K, Owaki T, Nakamura T, Kitamura F, Miyamoto N. Clinical application of transvenous mitral commissurotomy by a new balloon catheter. The Journal of thoracic and cardiovascular surgery. 1984 Mar;87(3):394-402.

21. Vahanian A, Michel PL, Cormier B, Vitoux B, Michel X, Slama M, Sarano LE, Trabelsi S, Ismail MB, Acar J. Results of percutaneous mitral commissurotomy in 200 patients. The American journal of cardiology. 1989 Apr 1;63(12):847-52. https://doi.org/10.1016/0002-9149(89)90055-6

22. Schenk P, Globits S, Koller J, Brunner C, Artemiou O, Klepetko $W$ et al. Accuracy of echocardiographic right ventricular parameters in patients with different end-stage lung diseases prior to lung transplantation. J Heart Lung Transplant 2000;19:145-54.https://doi.org/10.1016/S10532498(99)00121-7

23. Miller D, Farah MG, Liner A, Fox K, Schluchter M, Hoit BD. The relation between quantitative right ventricular ejection and indices of tricuspid annular motion and myocardial performance. J Am SocEchocardiogr 2004;17:443-7.https:// doi.org/10.1016/j.echo.2004.01.010

24. Lee TM, Su SF, Chen MF, Liau CS, Lee YT. Changes of left ventricular function after percutaneous balloon mitral valvuloplasty in mitral stenosis with impaired left ventricular performance. International journal of cardiology. 1996 Oct 25;56(3):211-5.https://doi.org/10.1016/0167$5273(96) 02734-9$

Cite this article as: Bishal KC, Rabi Malla, Ram Kishore Shah, et.al. immediate impact of percutaneous transvenous mitral commissurotomy on right ventricular function. Nepalese Heart Journal 2017; 14(2): 19-24. http://dx.doi.org/10.3126/njh. v14i2.18498
25. Borer JS, Hochreiter C, Rosen S. Right ventricular function in severe non-ischaemic mitral insufficiency. European heart journal. 1991 Jul 1;12(suppl B):22-5.https://doi.org/10.1093/ eurheartj/12.suppl_B.22

26. Malhotra V, Beohar PC, Gondal R, Kaul UA, Khanna SK. An Autopsy Study of Rheumatic Heart Disease. Japanese heart journal. 1987;28(1):7-14.https://doi.org/10.1536/ihj.28.7

27. Iskandrian AS, Hakki AH, Ren JF, Kotler MN, Mintz GS, Ross J, Kane SA. Correlation among right ventricular preload, afterload and ejection fraction in mitral valve disease: radionuclide, echocardiographic and hemodynamic evaluation. Journal of the American College of Cardiology. 1984 Jun 1;3(6):1403-11.https://doi.org/10.1016/S07351097(84)80278-8

28. Ragab AM, Mohamed A, Amr A, Tamer M. Usefulness of non-invasive right ventricular function assessment in prediction of adverse events after successful balloon mitral valvuloplasty. Journal of basic and applied scientific research. $2011 ; 1: 260-8$

29. Bensaid A, Krapf L, Malanca M, Brochet E, Iung B, Vahanian A, Messika-Zeitoun D. Echocardiographic right ventricular function assessment before and after successful percutaneous mitral commissurotomy. The Journal of heart valve disease. 2011;20(6):627-32

30. Kundu SK, Majumder AA, Halder D, Chakrovortty SK, Khan MR, Dutta B, Karmoker KK, Ahmed M. Immediate Impact of Percutaneous Transvenous Mitral Valve Commissurotomy (PTMC) on Right Ventricular Function. Cardiovascular Journal. 2012 16;5(1):3-11.

31. Borges AC, Knebel F, Eddicks S, Panda A, Schattke S, Witt C, Baumann G. Right ventricular function assessed by twodimensional strain and tissue Doppler echocardiography in patients with pulmonary arterial hypertension and effect of vasodilator therapy. The American journal of cardiology. 2006;98(4):530-4. https://doi.org/10.1016/j.amjcard.2006.02.060 